\title{
The Engaged Specific Intellectual: Resisting Unethical Prison Tourism and the Hubris of the Objectifying Modality of the Universal Intellectual Craig Minogue
}

$\mathrm{I}_{\mathrm{t} i \mathrm{~s}}^{\mathrm{b}}$

egin this article by arguing for an important matter of style by identifying

the sociological position from which I write and justify my ideological position with reference to the modality of work done by Michel Foucault. In examining prison tourism, I will criticize the work of academics like Fred Alford and Loïc Wacquant who do not critically engage with the power relations of the prison, but rather allow themselves to be co-opted as privileged actors when they tour prisons. I argue that academic objectivism translates as an act of hubris when one side of a knowledge-producing power relationship is joined by those participating in prison tourism. I conclude this paper with a discussion on how Michel Foucault's thesis of the specific intellectual provides an example of a modality of work that can allow the possibility of prison tours to be run ethically under certain circumstances.

\section{Academics and Positionality}

Firstly, to that matter of style which needs to be addressed. I will refer to people throughout this essay by their full proper names, for as Paul Ricoeur (1992, p. 29) says in his seminal Oneself as Another, "the privilege accorded the proper names assigned to humans has to do with their subsequent role in confirming their identity and their selfhood". In most academic disciplines it is common practice to refer to one's fellows in professional journals and other written work by the collegial use of second names only. This practice is no doubt a kind of shorthand, but I read it as a type of elitism and thus a language of exclusion. Discipline does not end in the academy, for as a verb the word 'discipline' means the practice of imposing obedience and punishment on another person. This discipline is a personal rebuke and in these types of disciplinary systems the person who is rebuked is most often stripped of his or her social and human character and objectivised in a way to suit the particular disciplinary project, be that of the prison, the military or other total institutions like English public schools. My academic discipline is that of the humanities, of philosophy, applied ethics and morality. I write however from within the physical discipline of the prison where the loss 
of the horrific "Mr" along with the loss of one's first name are not at all collegial experiences for me, but excluding, objectivising and dehumanizing ones. For these reasons I try to break with this particular academic tradition of using second names only whenever I can in my work; perhaps as you read you will see the humanizing effect which I think this achieves.

Like every person, I view and analyse my situation from within particular frames of sociological and ideological reference. Sociologically I am positioned as a highly differentiated and marginalized other, that is a person serving a life sentence for a serious crime I committed almost a generation ago - a crime that lives on and, in fact, has a life of its' own in the public imagination through sensationalist news and infotainment media.

Through my peer reviewed publishing, court actions and other jailhouse lawyer activities I am also positioned as an academic and an activist. Dylan Rodríguez (2006, p. 110) would say that I am an 'imprisoned radical intellectual'. Black Panther Marshall Eddie Conway would say that I am a 'political prisoner'. Henry Giroux (2005, p. 190) would say that I am an 'oppositional academic'. Of course, the prison administrators think I am a 'troublemaker' (Carlton, 2007, p. 155, 236). Ideologically I see myself as what Michel Foucault called a 'specific intellectual', that is a person who works 'not in the modality of the 'universal', the 'exemplary', the 'just-andtrue-for-all', rather he or she works "within specific sectors, at the precise points where their own conditions of life or work situate them" (May, 1993, p. 6 and Foucault, 1980, p. 126). As Todd May says:

Rather than standing above or outside their society, 'specific intellectuals' are immersed within it. They cite, analyse, and engage in struggles not in the name of those who are oppressed, but alongside them, in solidarity with them, in part because others' oppression is often inseparable from their own. This type of intervention allows them to embrace the oppression that 'universal intellectuals' used to analyse and to understand it better than the latter did, because rather than pronouncing on the fate of others from on high or outside, they carry with them an experience of the kind that belongs to the oppressed themselves (May, 1993, pp. 6-7).

I argue that universal intellectuals, those who believe that they can stand outside of power relations and make pronouncements about the practices found there are engaged in an act of intellectual hubris and indignity. 
Gilles Deleuze said that Michel Foucault's work demonstrated that there was an inherent 'indignity' associated with 'speaking for others', as well as with intellectuals taking a universal and objective view from the outside of power relations. Again Todd May best summarises this position highlighted by Gilles Deleuze when he says of Michel Foucault's work that when

...it came to strategies for action, he preferred to listen to the oppressed rather than to act as the standard-bearer for their 'liberation'. Instead he offered specific historical analyses that were useful for their struggle. The name he gave to one who performed this type of work was the 'specific intellectual' (May, 1993, p. 6).

Before I make the distinction between a specific and universal intellectual clear, it needs to be kept in mind that the prison is a knowledge-producing discourse, especially when it comes to the emergence of a sense of good self and bad other.

A specific intellectual works ethically with others by subjectively asking in an engaged way: "What would it be like in the prisoner's shoes?" To consider the interests of others as if they are your own subjective interests is at the heart of modern secular ethics and morality. The specific intellectual thus views the prison from the perspective of the powerless and this vantage point cannot help but to open up possibilities in the otherwise closed normative sense of good self as oppositional to the bad other.

The universal intellectual works by objectively asking in a neutral way: "What are the facts of the situation?" So to tour a prison with a guard at one's side and penetrate prisoners with one's silent gaze as if they were occupants of a zoo, the universal intellectual is only able to hear one side of the knowledge producing discourse of power relations. The universal intellectual, a good self who goes home at the end of the day, thus views the prison from the perspective of the powerful. From this vantage point, he or she cannot help but to perpetuate a normative sense of good self as oppositional to the bad other people who are not allowed a voice like those others in the zoo.

I approach the issue of prison tourism from my personally and particularly engaged perspective as a prisoner, not from that of a privileged academic researcher. That some leading academic researchers do not understand their 
privileged position is staggering. Working in the American prison system, academics like Fred Alford (2000, p. 142) boast of their position in the prison as one like "an unpaid staff member with an official position, that of researcher... [with] a staff badge". A sharp distinction needs to be made here. I am not a privileged actor with a 'staff badge' and the freedom to roam around the prison at my self-directed will. My piece of plastic identifies me as 'Prisoner' and this is a categorization that serves to restrict every bodily movement does not open doors like Fred Alford's 'staff badge'. My badge, my label closes doors and spaces on me and from me, for as a prisoner I am a person against whom disciplinary power is directed. Fred Alford not only implicitly rejects the modality of the specific intellectual; from his privileged position in an unequal power relation, he explicitly argues that Michel Foucault got it all wrong (Alford, 2000).

Loïc Wacquant writes in his 'field notes' of a guided tour of a prison that he feels like "a voyeur, an intruder" and that he "would like to say, 'I'm sorry to disturb you,' [to the prisoners] but it would be incongruous" (Wacquant, 2002, p. 378). Yes, it would be incongruous, that is, it would be out of place because he is a privileged actor in an unequal power relationship. With a prison guard at his side and the freedom to leave when he chooses, Loïc Wacquant's position is apart from and above that of the prisoners he gazes upon; he is co-opted and positioned by the prevailing power relations and his view and understanding cannot help but be shaped by this positioning. Loïc Wacquant's feelings of horror at the "ongoing visual and sensory penetration" that the prisoners are suffering and which turns them into objects, has in his own words, "infringed on the dignity of human beings by the mere fact of having been there and seen that place, and thus to have treated its denizens as one might the occupant of a zoo" (Wacquant, 2002. p. 378, 381). So, Loïc Wacquant concedes that prisoners are humiliated, stripped of humanity and objectivised by prison tours like the ones he participates in, but he seems to take a 'how could it be otherwise' attitude.

Perhaps things would have been different if, when Loïc Wacquant felt this horror and this infringement of the dignity of others, he had stopped, squatted down on his haunches and stuck his hand through the bars to a man on his bunk and said "Hello I am Loïc Wacquant, an academic doing research about the prison, how are you doing?" If Loïc Wacquant had done this, it is my guess that his gaze would not have been so penetrative. Perhaps when he made eye contact with that person behind the bars on the 
bunk he would have created a space for humanity. Perhaps when grasping that other person's hand he would have created a "territory of intimacy" and acted against what he obviously thinks is the wrong way to treat others (Wacquant, 2002, p. 378). Loïc Wacquant seems to understand that he is not a neutral or objective actor. Rather, he is a subjective participant in the unequal and unjust power relations, but he simply laments the fact that he can not give ethical character to his actions, precluding discussion on how the situation could have resisted or how it could have been made otherwise. By working in this way, Loïc Wacquant joined with the normative values of the dominant discourse of the inequitable power relations of the prison. And this joining was done, no doubt, for the sake of being objective, but the problem with the objective view taken is that the dominant normative discourse is the default position from which one takes the view. That the discourse and the knowledge he is analyzing emerged from the power relations of the guard at his side, the institution, the law, the State, popular opinion, a pop-cultural gorging on crime $\mathrm{TV}$, and finally of the prisoners behind the bars and solid doors of their confinement seems to have escaped Loïc Wacquant. To be fair, he does 'feel' the problem, he does experience the 'embarrassment' of people being treated as if they are "occupants of a zoo" (Wacquant, 2002, p. 381). But what does he do? What 'action' is this feeling translated into?

To make matters worse, Loïc Wacquant then misreads Michel Foucault as a 'historical diagnosis of the present' in materialistic and objective terms, and says 'he could not have been more wrong', having missed the genealogical method and the subjective approach that Michel Foucault took in Discipline and Punish (1977) in relation to exploring the emergence of a disciplinary subject; that is of a sense of the self as compliant (docile) to the disciplinary project of the carceral (Wacquant, 2002, p. 384). Foucault's Discipline and Punish is not about prison buildings, it is not a history of punishment or the prison, it is not about the activities of the prisoners therein. What it is primarily concerned with is "a correlative history of the modern soul [self] and of a new power to judge" (Foucault, 1977, p. 23). This power to judge and the construction of a sense of self and other is one that emerges through the public discourse of normative values around crime and punishment. That the emergence of a sense of self through the dominant discourse is the main focus of Michel Foucault's work throughout Madness and Civilization (1965), The Birth of the Clinic (1973), and Discipline and 
Punish (1977). The point about the emergence of self is highlighted in the History of Sexuality Volume I an Introduction, where it is demonstrated that a normative dominant discourse of heterosexual relations creates a culturally specified discursive imperative against homosexuality by not allowing homosexuality to be seen or heard in its own light (Foucault, 1980a).

Intellectuals like Fred Alford and Loïc Wacquant position themselves to tell others about the experience of their oppression rather than drawing from the lived situation at hand and analyzing its particular truth and its particular place in the lives people actually live (May, 1993, p. 7). A good example of the work of Michel Foucault's specific intellectual, that is one that draws from a lived situation, is Drew Leder's (2004) Imprisoned Bodies: The LifeWorld of the Incarcerated. The task of the specific intellectual is to stand, as Todd May put it so well:

In solidarity with those whose situation forces them to struggle. The task confers upon the intellectual no privileged status. The intellectual has no more authority than the doctor or the lawyer to speak the truth or the meaning of others' struggles, and certainly no more than those who face their oppression daily. He or she is one of them in his or her own oppression, and beside them in theirs. It is a role of the walk-on, not the director (May, 1993, p. 7).

A 'staff badge' makes one a director, just as the silent penetrative gaze of people of prison tours contribute to prisoners being treated as objects. These activities position the academics who are touring prisons on the allpowerful side of unequal power relations and limits their understanding of the situation, and makes the situation of the oppressed worse. The way in which academics like Fred Alford and Loïc Wacquant's work highlights "the two contrasting pictures of knowledge that Michel Foucault identifies in Discipline and Punish" (May, 1993, p. 72). Again, as Todd May explains so well:

...the traditional liberal view, which holds that knowledge occurs in the absence of relations of power; the other is the genealogical view, which sees knowledge arising as a product of power/knowledge. From the traditional perspective, the subject of power lies at the source of knowledge, giving rise to knowledge and subsequently to power: hence, subjective 
foundationalism and the importance of the mind. For genealogy, on the other hand, the subject comes later; it is a product of power-knowledge relationships, of the matrices formed by the interplay between knowledge and power, not their source (ibid).

The 'liberal view' that Todd May talks about here is that of the universal intellectual who works in what he or she presumes is a neutral modality and reports on the facts as they appear. The 'genealogical view' is that of the specific intellectual who looks past the way things are and asks how they became the way they are perceived to be. The specific genealogical intellectual asks how a sense of self emerged from the power/knowledge relations and seeks to expose those processes of emergence. The universal neutral/objective intellectual presumes that self is already formed and that power/knowledge act upon that sense of self and other. I believe that I have made a good case for the serious problems associated with academic tours and work in the prison, especially when academics ostensibly try to be objective. In actuality, they are co-opted by the dominant normative discourse of the power relations found in the prison, and the subsequent emergence of a sense of self and other for the prisoners and those who are penetrating them with their gaze.

\section{Notes on the Merits and Ethics of Prison Tours}

In my $2003 J P P$ article, "Human Rights and life as an attraction in a correctional theme park", I exposed my feelings of objectification and my experiences of prison tourism and its inequitable power relations, so I will not repeat those facts and that analysis here (Minogue, 2003, pp. 44-57). I will, however, now move on to address the other specific issues that have been raised by the $J P P$ about prison tourism.

Before I answer the specific questions put by the $J P P$ on prison tours and make suggestions for how an ethical tour can be run, I need to secure the position from which I will do that. The work of Michel Foucault illuminates this position. While he does not provide a program of action to resist unjust power or wrong, Michel Foucault provides a mode of analysis that allows the people concerned - prisoners and people working with them in this case - to develop their own program. This illustrates the issue of pronouncements that has been mentioned a number of times and 
which has perhaps not been fully appreciated. The universal intellectual makes an objective sounding pronouncement: this is what is happening and this is what should be done about it. A specific intellectual says: I have immersed myself in the power/knowledge relations in solidarity with the oppressed and I have excavated a genealogy that indicates how things have come to be perceived as being this way. That analysis is then made available to the oppressed and they can see how their situation has come to be, and then use that understanding as a tool to develop a program of resistance for themselves. To criticize Michel Foucault for not providing a program, misses the distinction of his modality of work from that of the universal intellectual to the specific intellectual who seeks to empower people who's sense of self emerges through the power/knowledge relations like those found in the prison.

\section{Can a Prison Tour Be Run Ethically?}

The short answer is 'yes', but there is a 'however'. Before arguing for how a prison tour can be run ethically, I need to define my terms. Put simply, 'ethics' deals with considering the morally relevant interests of people in relation to an intended action which will affect their interests. Although there are interests that are common to all people, like avoiding unnecessary pain and suffering - I say 'unnecessary' because pain and suffering can be necessary like that associated with a medical procedure to save one's life then there are specific interests in relation to issues of, say, gender, religion, culture, and yes those interests associated with being a person imprisoned by the State.

The reality is that there are some interests which are intruded upon as a necessary implication of the processes of mass imprisonment of millions of people as a punishment (not all in the one place yet). There is a discrete and a discreet nature to these things, which are shared within the environment by prisoners and the guards. The first thing that comes to mind is the interest of privacy. For example, conducting ablutions in front of other people is not only undignified but because of the bad design of some prisons, it is a necessary indignity and a shared indignity. The interest that people have in not making this type of indignity worse or more public than it already is by the circumstances of imprisonment is an important one and it is one indignity whose violation I have experienced as a result of prison tourism (Minogue, 2003, p. 45). 
Loïc Wacquant rightly claims that prison tours offer "a propitious vantage point from which to contribute to the comparative ethnography of the state" (Wacquant, 2002, p. 389 - original emphasis). But, for a prison tour to be run ethically the outsiders participating in it must give consideration to the morally relevant interests of the people involved. Loïc Wacquant clearly identified the problem of his penetrative gaze and the infringement inherent in his presence in the prison and how he later felt dirty and embarrassed (Wacquant, 2002, pp. 378, 381). One important way that moral consideration can be given so the tours are conducted ethically is to allow the people who are the 'subjects' concerned, to speak for themselves. In Australia and North America, and I am sure other regions, those people who are imprisoned such as radical intellectuals, political prisoners, oppositional academics, and the plain old prison activist or specific intellectual, are well known to lawyers, law faculties and social justice NGOs. So if a tour is contemplated, those people should be contacted and asked how a tour could be ethically conducted, that would respect the interests of the people in the prison. Once advice has been received, those wanting to tour would then write to the prison administration and say that they consider the prison to be a remote and isolated community that has particular norms and sensitivities, and as such they have approached people incarcerated in the prison and asked for their thoughts on how a tour could best be conducted so as not to offend their morally relevant interests. Then set out the concerns that have been expressed and ask that the prison administration enter into a dialogue about how to best meet those concerns, as well as the concerns and requirements of the administration. If the prison administration is not willing to enter into this dialogue or consider the morally relevant interests of the people in their prison then this should speak very loudly against any tour being able to be ethically conducted or being of any academic or sociological value.

\section{Can Prison Tours be an Effective Strategy to Reveal the Realities of Imprisonment?}

The short answer is 'yes', but again there is a 'however'. If the people in the prison are involved in the process, if there is a dialogue before, during and after the tour, then I believe that there can be an enormous benefit in revealing the realities of imprisonment. Of course a lot depends on which prisoners are part of this process. Anyone wanting to have a tour would need to be sceptical of the prison administration nominating prisoners to be 
involved. In the prison system here, prisoner representatives and those who are allowed to talk to visitors on tours are selected by the staff. There is no 'application form' or process of prisoners deciding who their representatives are. Prisoners can apply for Peer Educator or Peer Supporter roles, but the staff decide who is employed in those positions. Prisoners who unofficially do this work, like me, are targeted by the prison administration for retaliation (Minogue, 2008). The activist, who is ideologically and morally committed to his or her actions in resisting the unnecessary inequalities, will do so despite, or perhaps in spite of, being targeted for retaliation by the prison administration.

\section{Do Prison Tours Have Any Merit?}

The short answer is 'no', not as they are currently run, but there is a 'however' here as well. If prison tours were run with appropriate prisoner consultation beforehand and participation during the tour and then after, tours could have merit.

\section{What Do I Foresee as an Ethical and Meritorious Prison Tour?}

I have touched upon this issue above, so I will restate in point form that which has already been mentioned and then add more substantively to that which has not yet been dealt with. An ethical prison tour would look something like this:

- Make contact with the appropriate prisoners - if those wanting a tour are unable to make this contact then I would question how relevant the tour can be if the people wanting to tour are so out of touch with lawyers, law faculties and social justice NGOs working around prison issues;

- State the purpose and the aims of the tour;

- Ask for advice as to how a tour could be conducted in such a way as it gave proper consideration to the legitimate interest of the people incarcerated in the prison;

- Approach the prison administration requesting a tour and a dialogue about how that tour will be undertaken with consideration to the advice received from prisoners; and

- Re-contact the prisoners and advise them of the outcomes of the dialogue with the prison administration in relation to how the tour is 
to be conducted and ask if they are willing for the tour to go ahead under those circumstances.

If academics or students were to be visiting say, a remote indigenous community or an isolated religious community that lived apart from the modern world, then it is my expectation that such a process of consultation would be undertaken with the leaders of people in those communities leaders who have been empowered by the community and not appointed by people outside the community. Would a university ethics committee allow a tour of a remote indigenous community on the approval of the local governmental authorities only or would the committee require some type of consultative process like I have suggested? I think and hope the answer would be "yes, a consultative process is required", so why should it be any different for the prison? I have found that, here in Australia, there is no ethics committee process for academics and students who engage in prison tours; the universities reason they are not responsible as the prison lets them do it (Minogue, 2003, pp. 53-54). That the State malevolently holds people by life threatening levels of force does not exclude normal ethics committee involvement, rather it should make it an imperative. I have argued this before in my 2003 JPP article but the point can do with being restated. Think of the way in which prison tours have and are being run, and transfer that modality to any other remote and isolated community with members who are vulnerable to their interests not being properly considered by outsiders who are visiting and this will illustrate the problem of inadequate consultation, as well as the real need for it to be done ethically. Imagine an academic touring a remote indigenous community with the authority of the local police officer and no community consultation beforehand; no academic who wanted to keep their job would do such a thing. However, so accepting of the normative discourse of prisoners being less than human, being animal-like creatures who have forfeited any moral consideration of their pain and suffering, academics do in the prison what they would not think of doing in any other situation. How can they not see this? What value does their work hold if they are so myopic?

\section{But How Would the Tour Be Conducted in Practice?}

It is my view that the prisoners who were contacted for advice should meet the people doing the tour at the closest point possible to their entry and 
then accompany the group or individual and escorting officer on the tour of prisoner areas. If this was the case the prisoner could:

- Introduce the people on the tour to prisoners he or she feels may have something relevant to say or ask relevant questions of prisoners to initiate a dialogue between the visitors and the prisoners;

- Suggest areas to visit;

- Pause on the tour and include historical information about particular areas from a prisoner's point of view;

- Draw attention to particular problems in situ; and

- Engage in a dialogue with the group in response to the commentary of the escorting officer.

The dialogue is of the utmost importance. I do not know about the scripts for prison tours by prison administrators in North America, but I know that in Australia the "passing of verbal communication" (the prisons' words) by prisoners to persons on a tour is considered to be like the "passing" of contraband to prisoners (Minogue, 2003, p. 47). Prisoners are not allowed a voice - they are like children of old, to be seen but not heard.

Would the prison allow such an interactive participatory process? I think that most people reading this essay would laugh and answer "no way, man". If that is the case then what does this say about the tours as they are now conducted? This should then be the focus of academic inquiry: to consider why the prison wants to control the outcome of a tour, and then to critically assess the value of the tour as "a comparative ethnography of the state" (Wacquant, 2002, p. 389 - original emphasis).

\section{After the Tour}

The people on the tour should reflect on the tour, along with what was said before and after prisoners joined the tour group or individual. Did the escorting staff member seek to preface or undermine issues that prisoners raised? Did the prison officer seek to "play the man and not the ball" in relation to the issues raised by prisoners? If so, then those who undertook the tour need to reflect on what that means, and then communicate with the prisoners again and ask for their point of view. After this process, then consider the whole picture and what was gained from the tour. 
These suggestions for how prison tours can be conducted ethically depend largely on the prisoners who are approached for their advice, and on whether or not prison authorities will allow them to participate in this way. If prison authorities will not allow this type of prisoner participation and balk at the approach taken by the people wanting to do a prison tour, then this speaks to the type of tour that they would experience if solely conducted by prison authorities - unethical and unmeritorious. If prison authorities balk, then the experience of trying to arrange an ethical tour can be written up for a journal article or an opinion piece in a progressive newspaper. A complaint can be made also to an appropriate authority or the political branches of government. The issue also can be agitated around the openness and accountability of public institutions. What should not be done is for the tours to continue as they are now; that would be truly incongruous, because when an academic thinks "how could it be otherwise" they are not really thinking and the unthinking academic should have no place in the public dialogue about imprisonment.

- Somewhere in the carceral archipelago.

\section{ENDNOTES}

${ }^{1}$ English 'public' schools are what the rest of the world would call a 'private' school.

\section{REFERENCES}

Alford, Fred C. (2000) "What Would It Matter If Everything Foucault Said About Prison Were Wrong? Discipline and Punish After Twenty Years", Theory and Society, 29(1): 125-146.

Carlton, Bree (2007) Imprisoning Resistance: Life and Death in an Australian Supermax, Sydney: Institute of Criminology Press.

Foucault, Michel (1980) The History of Sexuality (Volume One), Robert Hutley (trans.), New York: Vintage.

Foucault, Michel (1977) Discipline and Punish: The Birth of the Prison, Alan Sheridan (trans.), New York: Vintage Books.

Giroux, Henry A. (2005) Against the New Authoritarianism: Politics After Abu Ghraib, Manitoba: Arbeiter Ring Publishing.

Leder, Drew (2004) "Imprisoned Bodies: The Life-World of the Incarcerated", Social Justice, 31(1-2): 51-66. 
May, Todd (1993) Between Genealogy and Epistemology: Psychology, Politics, and Knowledge in the Thought of Michel Foucault, Pennsylvania: The Pennsylvania State University Press.

Minogue, Craig (2008) "“What's it got to do with you?' A defence of the jail-house lawyer", unpublished paper - extracts read by Colm McNaughton on "Inside China's Prisons, Swinging open China's cell doors to hear who's inside, and why", Radio New Internationalist (www.newint.org/radio) - July 20.

Minogue, Craig (2003) "Human Rights and life as an attraction in a correctional theme park", Journal of Prisoners on Prisons, 12: 44-57.

Ricoeur, Paul (1992) Oneself as Another, Chicago: University of Chicago Press.

Rodríguez, Dylan (2006) Forced Passages: Imprisoned Radical Intellectuals and the U.S. Prison Regime, Minneapolis: University of Minnesota Press.

Wacquant, Loïc (2002) "The curious eclipse of prison ethnography in the age of mass incarceration”, Ethnography, 3(4): 371-397.

\begin{abstract}
About the Author
Craig W.J. Minogue has survived prison since 1986. His release date is in 2016. Completing a multi-disciplinary BA (Honours) in 2005, which was his first formal educational achievement, he is now working on his $\mathrm{PhD}$ in Applied Ethics at La Trobe University. Craig is a social justice advocate who assists fellow prisoners with equitable access to courts, information about the law, educational programs and health services. By necessity, he is also an unofficial volunteer crisis and acute mental health care worker. Craig is a regular contributor to community legal education projects and he has peer-reviewed publications in the fields of philosophy, literature, criminal law, human rights and prison issues. He also creates art when he can and he has a number of works hanging in public buildings in Melbourne, Australia. $\mathrm{He}$ is currently in custody at Marngoneet Correctional Centre and can be contacted at craig2016@bigpond.au.
\end{abstract}

